\title{
Carbon isotopic signature of coal-derived methane emissions to the atmosphere: from coalification to alteration
}

\author{
Giulia Zazzeri $^{1}$, Dave Lowry ${ }^{1}$, Rebecca E. Fisher ${ }^{1}$, James L. France ${ }^{1,2}$, Mathias Lanoisellé ${ }^{1}$, Bryce F. J. Kelly ${ }^{4}$, \\ Jaroslaw M. Necki ${ }^{3}$, Charlotte P. Iverach ${ }^{4}$, Elisa Ginty ${ }^{4}$, Miroslaw Zimnoch ${ }^{3}$, Alina Jasek ${ }^{3}$, and Euan G. Nisbet ${ }^{1}$ \\ ${ }^{1}$ Royal Holloway University of London, Egham Hill, Egham, Surrey TW20 0EX, UK \\ ${ }^{2}$ University of East Anglia, Norwich Research Park, Norwich, Norfolk NR4 7TJ, UK \\ ${ }^{3}$ AGH-University of Science and Technology, Al. Mickiewicza 30, Kraków, Poland \\ ${ }^{4}$ Connected Waters Initiative Research Centre, UNSW, Sydney, Australia \\ Correspondence to: Giulia Zazzeri (giulia.zazzeri.2011@live.rhul.ac.uk) and Euan G. Nisbet (e.nisbet@es.rhul.ac.uk)
}

Received: 17 March 2016 - Published in Atmos. Chem. Phys. Discuss.: 30 March 2016

Revised: 16 September 2016 - Accepted: 25 September 2016 - Published: 3 November 2016

\begin{abstract}
Currently, the atmospheric methane burden is rising rapidly, but the extent to which shifts in coal production contribute to this rise is not known. Coalbed methane emissions into the atmosphere are poorly characterised, and this study provides representative $\delta^{13} \mathrm{C}_{\mathrm{CH}_{4}}$ signatures of methane emissions from specific coalfields. Integrated methane emissions from both underground and opencast coal mines in the UK, Australia and Poland were sampled and isotopically characterised. Progression in coal rank and secondary biogenic production of methane due to incursion of water are suggested as the processes affecting the isotopic composition of coal-derived methane. An averaged value of $-65 \%$ o has been assigned to bituminous coal exploited in open cast mines and of $-55 \%$ in deep mines, whereas values of -40 and $-30 \%$ can be allocated to anthracite opencast and deep mines respectively. However, the isotopic signatures that are included in global atmospheric modelling of coal emissions should be region- or nation-specific, as greater detail is needed, given the wide global variation in coal type.
\end{abstract}

\section{Introduction}

Methane emissions from the energy sector have been driven in recent years using the impact of a shift from coal to natural gas, in the US and Europe, whereas in China coal production has increased over this century. Currently, the atmospheric methane burden is rising rapidly (Nisbet et al., 2014), but the extent to which shifts in coal production contribute to this rise is not known. Coalbed methane emissions into the atmosphere are poorly characterised, as they are dispersed over large areas and continue even after a mine's closure (IPCC, 2006). Methane is emitted in coal processing (crushing and pulverisation) and, during the initial removal of the overburden, it can be diluted and emitted through ventilation shafts in underground coal mines or directly emitted to the atmosphere from open-cut coal mining, where releases may occur as a result of deterioration of the coal seam.

For the UN Framework Convention on Climate Change, national emissions are estimated by a bottom-up approach, based upon a general equation where the coal production data are multiplied by an emission factor that takes into account the mine's gassiness, which in turn is related to the depth of the mine and the coal rank (i.e. carbon content of coal) (US EPA, 2013). These modelled estimates are often reported without an error assessment; therefore the level of accuracy of the emissions is not known. Top-down assessment of methane emissions can be made by chemical transport models constrained by atmospheric measurements (Bousquet et al., 2006; Locatelli et al., 2013). However, this top-down approach provides the total amount of methane emissions into the atmosphere, which has to be distributed among the different methane sources in order to quantify each source contribution.

For methane emissions from fossil fuels (coal and natural gas), the source partitioning is mainly bottom-up, based on energy use statistics and local inventories, which might be highly uncertain. Conversely, the top-down study of the 
carbon isotopic composition of methane, which is indicative of the methane origin, provides a valuable constraint on the budget appraisal, allowing different sources in a source mix to be distinguished and their individual strength to be evaluated (Hein et al., 1997; Liptay et al., 1998; Lowry et al., 2001; Townsend-Small et al., 2012).

Measurements of methane mole fractions can be complemented in atmospheric models by typical $\delta^{13} \mathrm{C}_{\mathrm{CH}_{4}}$ signatures of the main methane sources in order to estimate global and regional methane emissions and assess emissions scenarios throughout the past years (Fung et al., 1991; Miller, 2004; Whiticar and Schaefer, 2007; Bousquet et al., 2006; Monteil et al., 2011; Mikaloff Fletcher et al., 2014). However, even though isotopic values are fairly distinctive, for specific methanogenic processes, the variety of production pathways and local environmental conditions that discriminate the methane formation process leads to a wide range of $\delta^{13} \mathrm{C}_{\mathrm{CH}_{4}}$ values. The global isotopic range for coal is very large, from -80 to $-17 \%$ (Rice, 1993), but it can be narrowed down when a specific basin is studied. While there are several studies of isotopic composition of methane generated from coal in Australia, the USA and China (Smith et al., 1981; Dai et al., 1987; Rice et al., 1989; Aravena et al., 2003; Flores et al., 2008; Papendick et al., 2011), there is a significant lack of information about the isotopic characterisation of methane emissions from coal mines in Europe.

The purpose of this study was to determine links between $\delta^{13} \mathrm{C}_{\mathrm{CH}_{4}}$ signatures and coal rank and mining setting, and to provide representative ${ }^{13} \mathrm{C}$ signatures to be used in atmospheric models in order to produce more accurate methane emission estimates for the coal exploitation sector.

\section{Process of coalification and parameters affecting the $\delta^{13} \mathrm{C}$ signature of methane emissions}

The process of coalification involves both biochemical and geochemical reactions. The vegetal matter firstly decays anaerobically under water; the simple molecules derived from initial decomposition (i.e. acetate, $\mathrm{CO}_{2}, \mathrm{H}_{2}, \mathrm{NH}_{4}^{+}$, $\mathrm{HS}^{-}$, long chain fatty acids) are metabolised by fermentative archaea, which produce methane via two methanogenic paths: acetoclastic reaction or $\mathrm{CO}_{2}$ reduction (Whiticar, 1999). Different pathways lead to diverse $\delta^{13} \mathrm{C}_{\mathrm{CH}_{4}}$ isotopic signatures - methane from acetate is ${ }^{13} \mathrm{C}$ enriched relative to methane from $\mathrm{CO}_{2}$ reduction, ranging from -65 to $-50 \%$ o and -110 to $-50 \%$ o respectively (Levin et al., 1993; Waldron et al., 1998). With increasing burial and temperatures, coal is subjected to thermal maturation, which implicates more geochemical changes.

As coalification proceeds, the carbon content increases, accompanied by a relative depletion in volatile compounds, such as hydrogen and oxygen, emitted in the form of water, methane, carbon dioxide and higher hydrocarbons through decarboxylation and dehydration reactions (Stach and Murchison, 1982). At higher degrees of coalification and temperature, the liquid hydrocarbons formed in previous stages are thermally cracked to methane, increasing the amount of methane produced (Faiz and Hendry, 2006). Peat and brown coal represent the first stage of the coalification process. The vertical pressure exerted by accumulating sediments converts peat into lignite. The intensification of the pressure and heat results in the transition from lignite to bituminous coal, and eventually to anthracite, the highest rank of coal (O'Keefe et al., 2013).

During peat and brown coal stages, primary biogenic methane is formed and it is mainly dissolved in water or released during burial, as coal is not appropriately structured for gas retention (Kotarba and Rice, 2001). At more mature stages, thermogenic methane is produced by thermal modification of sedimentary organic matter, which occurs at great depths and intense heat. Following the basin uplift, methane production can be triggered in the shallower sediments by the meteoric water inflow into the coal (secondary biogenic gas) (Rice, 1993; Scott et al., 1994).

The isotopic signature of the methane produced during the coalification process is controlled by the methane origin pathway (Whiticar, 1996). Thermogenic methane is isotopically enriched in ${ }^{13} \mathrm{C}\left(\delta^{13} \mathrm{C}>-50 \%\right.$ ) compared to biogenic methane, as methanogens preferentially use the lightest isotopes due to the lower bond energy (Rice, 1993). Intermediate isotopic compositions of methane might reflect a mixing between microbial and thermogenic gases or secondary processes. Indeed, many controlling factors co-drive the fractionation process, and several contentions about their leverage still persist in literature. Deines (1980) asserts that no significant trend is observed in the isotopic signature of methane in relation to the degree of coalification. Conversely, Chung et al. (1979) observed that the composition of the parent material does affect the isotopic composition of the methane accumulated. While the link between isotopic composition and coal rank is not that straightforward, studies carried out in different worldwide coal seams confirm a stronger relationship between coalbed gas composition and depth. Rice (1993), using data from Australian, Chinese and German coalbeds, shows that shallow coalbeds tend to contain relatively isotopically lighter methane when compared to those at greater depths. In the presence of intrusions of meteoric water, secondary biogenic methane, being isotopically lighter, can be generated and mixed with the thermogenic gas previously produced. Colombo et al. (1966) documented a distinct depth correlation in the Ruhr coal basin in Germany, with methane becoming more ${ }^{13} \mathrm{C}$-depleted towards the surface zone, independently from coalification patterns. This tendency can be explained either by bacterial methanogenesis or by secondary processes such as absorption/desorption of methane. Also Scott (2002), in a study about coal seams in the Bowen Basin, Australia, ascribes the progressive methane ${ }^{13} \mathrm{C}$-enrichment with depth to the meteoritic recharge in the shallowest seams, associated with a 
higher bacterial activity and a preferential stripping of ${ }^{13} \mathrm{C}-$ $\mathrm{CH}_{4}$ by water flow.

The migration of methane from the primary zone as a consequence of local pressure release can affect the isotopic composition, since ${ }^{12} \mathrm{CH}_{4}$ diffuses and desorbs more readily than ${ }^{13} \mathrm{CH}_{4}$ (Deines, 1980), but the fractionation effect due to migration is less than $1 \%$ o (Fuex, 1980). A much larger variation in the isotopic composition is associated with different methanogenic pathways (variation of $\sim 30 \%$ ) and thermal maturation stage (variation of $\sim 25 \%$ ) (Clayton, 1998). The measurement of deuterium, coupled with $\delta^{13} \mathrm{C}_{\mathrm{CH}_{4}}$ values, would help to distinguish the pathways of secondary biogenic methane generation, acetoclastic reactions or $\mathrm{CO}_{2}$ reduction (Faiz and Hendry, 2006), but such distinction is beyond the scope of this study.

Overall, the $\delta^{13} \mathrm{C}$ values of methane from coal show an extremely wide range, and understanding the processes driving the methane isotopic composition requires a focus on the particular set of geological conditions in each sedimentary basin.

Here we analyse the isotopic signatures of methane plumes emitted to the atmosphere, from the dominant bituminous and anthracite mines in Europe and Australia, of both deep and open-cut types, to test the theory of isotopic change due to coal rank.

\section{Material and methods}

\subsection{Coal basins investigated and type of coal exploited}

\subsubsection{English and Welsh coal mines}

Coal-derived methane emissions in the UK are estimated at $66 \mathrm{Gg}$ in 2013 (National Atmospheric Emissions Inventory, http://naei.defra.gov.uk), representing $0.4 \%$ of global emissions from mining activity (US EPA, 2012). The major coalfields of England and Wales belong to the same stage in the regional stratigraphy of north-western Europe (Westphalian Stage, Upper Carboniferous). Mining has ceased in many areas. Of those remaining, some are located in South Yorkshire (Hatfield and Maltby collieries), where $50 \%$ of the coalfield's output came from the Barnsley seam, which includes soft coal overlaying a semi-anthracitic coal and bituminous coal in the bottom portion.

The coal of the South Wales Basin exhibits a well-defined regional progression in rank, which varies from highly volatile bituminous coal in the southern and eastern margins to anthracite in the north-western part, and the main coalbearing units reach $2.75 \mathrm{~km}$ in thickness toward the southwest of the coalfield (Alderton et al., 2004). The coal is now preferentially extracted in opencast mines, as the extensive exploitation of the coal has left the accessible resources within highly deformed structures (e.g. thrust overlaps, vertical faults) that cannot be worked by underground min- ing methods (Frodsham and Gayer, 1999). Emissions from two deep mines, Unity and Aberpergwm, were investigated, where mine shafts reach depths up to approximately $750 \mathrm{~m}$ (http://www.wales-underground.org.uk/pit/geology.shtml).

\subsubsection{Upper Silesian Coal Basin in Poland}

The Upper Silesian Coal Basin extends from Poland to the Czech Republic and is one of the largest coal basins in Europe, with an area of $\sim 7400 \mathrm{~km}^{2}$ (Jureczka and Kotas, 1995), contributing $1.3 \%$ to global coal-derived methane emissions (US EPA, 2012). Emissions from the Silesian Region of Poland are estimated to be in the range of 450-1350 Gg annually (Patyńska, 2013). The Upper Carboniferous coal-bearing strata of this region are associated with gas deposits of both thermogenic and microbial origin, and the methane content and spatial distribution are coal rank related (Kędzior, 2009) - i.e. the sorption capacity of coal in the basin is found to increase with coal rank. Most of the methane generated during the bituminous stage in the coalification process has escaped from the coal source following basin uplift during the Palaeogene (Kotarba and Rice, 2001) and diffused through fractures and faults occurring in tectonic zones. The late-stage gas generated by microbial reduction of $\mathrm{CO}_{2}$ in the coal seams at the top of the Carboniferous sequence accumulated under clay deposition in the Miocene (Kędzior, 2009).

\subsubsection{Australia: Hunter Coalfield (Sydney Basin)}

The Hunter Coalfield is part of the Sydney Basin, on the east coast of New South Wales in Australia, and consists of three major coal measures. The deepest is the early Permian Greta Coal Measures, which is overlain by the late Permian Whittingham Coal Measures and upper Newcastle Coal Measures. Throughout the Hunter coalfield all sedimentary strata are gently folded, and the same coal seam can be mined at the ground surface and at depths of several hundred metres. In the region surveyed, both the opencast and underground mines are extracting coal from the Whittingham coal measures, which are generally high volatile bituminous coals, although some medium to low bituminous coals are extracted (Ward and Kelly, 2013). The mining operation is on a much larger scale than in the UK - the total coal production for the Hunter Coalfield was 123.63 Mt in 2011, of which $88.24 \mathrm{Mt}$ was saleable (State of New South Wales, 2013) and methane emissions are estimated to contribute $4.6 \%$ to global coalderived methane (US EPA, 2012). Several studies have attested to the dispersion of thermogenic methane formed at higher degrees of coalification (i.e. high temperatures and pressures) during the uplift and the subsequent erosion of the basin, followed by the replenishment of the unsaturated basin with more recently formed methane of biogenic origin (Faiz and Hendry, 2006; Burra, 2010). Gas emplacement is related to sorption capacity of coal strata, in particular to the pore pressure regime, which is influenced by the local geologi- 
cal features (compressional or extensional) of the basin. The south of the Hunter Coalfield is characterised by higher gas content and enhanced permeability than the northern area, with a large potential for methane production, mainly biogenic (Pinetown, 2014).

\subsection{Sampling and measurement methodology}

For isotopic characterisation of the methane sources, integrated methane emissions were assessed through detection of the off-site downwind plume. In fact, even when emissions are focused on defined locations, such as vent pipes in underground mines, the methane provenance cannot be localised, since most of collieries are not accessible. For sample collection and measurements of methane emissions downwind of coal mines in the UK and Australia, the mobile system described by Zazzeri et al. (2015) has been implemented. The system utilises a Picarro G2301 CRDS (cavity ringdown spectroscopy) within the survey vehicle, for continuous $\mathrm{CH}_{4}$ and $\mathrm{CO}_{2}$ mole fraction measurements, and a mobile module including air inlet, sonic anemometer and GPS receiver on the roof of the vehicle. The entire system is controlled by a laptop, which allows methane mole fractions and the methane plume outline to be displayed in real time on a Google Earth platform during the survey to direct plume sampling. When the plume was encountered, the vehicle was stopped and air samples collected in $3 \mathrm{~L}$ Tedlar bags, using a diaphragm pump connected to the air inlet. Samples were taken at different locations along the plume transect in order to obtain a wide range of methane mole fractions and isotopic signatures in the collected air. The Upper Silesian Basin was surveyed with a Picarro 2101-i measuring continuous $\mathrm{CO}_{2}$ and $\mathrm{CH}_{4}$ mole fractions and $\delta^{13} \mathrm{C}_{\mathrm{CO}_{2}}$ isotopic ratio. Samples were collected on site for analysis of $\delta^{13} \mathrm{C}_{\mathrm{CH}_{4}}$ isotopic ratio.

The carbon isotopic ratio $\left(\delta^{13} \mathrm{C}_{\mathrm{CH}_{4}}\right)$ of bag samples was measured in the greenhouse gas laboratory at RHUL (Royal Holloway University of London) in triplicate to high precision $( \pm 0.05 \%$ o by continuous flow gas chromatography isotope ratio mass spectrometry (CF GC-IRMS) (Fisher et al., 2006). $\mathrm{CH}_{4}$ and $\mathrm{CO}_{2}$ mole fractions of samples were measured independently in the laboratory with a Picarro G1301 CRDS analyser, calibrated against the NOAA (National Oceanic and Atmospheric Administration) WMO2004A and WMO-X2007 reference scales respectively. The $\delta^{13} \mathrm{C}_{\mathrm{CH}_{4}}$ signature for each emission plume was calculated using the Keeling plot approach, according to which the $\delta^{13} \mathrm{C}$ isotopic composition of samples and the inverse of the relative mole fractions have a linear relationship, with an intercept that represents the isotopic signature of the source (Pataki et al., 2003). Source signatures were provided with the relative uncertainty, computed using the BCES (Bivariate Correlated Errors and intrinsic Scatter) estimator (Akritas and Bershady, 1996), which accounts for correlated errors between two variables and calculates the error on the slope and intercept of the best interpolation line. Mole fraction data and co-located coordinates were used to map the mole fraction variability using the ArcGIS software.

\section{Results and discussion}

While most of the emissions from deep mines come specifically from ventilation shafts, which are point sources, emissions from open-cut mines are widespread, and difficult to estimate. However, the objective of this study is not the quantification of emissions, but the assessment of the overall signature of methane released into the atmosphere, made through the sampling of integrated emissions from the whole area. Therefore, even though on-site access to collieries was not possible, by driving around the contiguous area, methane emissions could be intercepted and their mole fractions measured. Table 1 summarises $\delta^{13} \mathrm{C}_{\mathrm{CH}_{4}}$ signatures of all the coal mines and coal basins surveyed with the Picarro mobile system.

\subsection{English coal mines}

Methane plumes from Hatfield colliery, one of the few British deep mines still open at the time of this study, were detected during surveys on 10 July and 26 September 2013. The methane desorbed from coal heaps within the colliery area and methane vented from shafts might explain the relatively high mole fractions measured (up to $7 \mathrm{ppm}$ ). Keeling plots based on the samples collected (4 on the first and 5 on the second survey) give intercept values of $-48.3 \pm 0.2$ and $-48.8 \pm 0.3 \%$ o (2 SD).

Maltby colliery is one of the largest and deepest mines in England and was closed in March 2013. The coal mine methane was extracted and used for electricity, but over 3 ppm mole fractions were detected in ambient air during both surveys in July and September 2013, giving evidence of methane releases from the recovery system and ventilation shafts. The Keeling plot intercepts based on the samples collected in July and in September are $-45.9 \pm 0.3$ and $-45.4 \pm 0.2 \%$ o (2SD) respectively, $\sim 3 \%$ o heavier than the isotopic source signatures calculated for Hatfield Colliery on the same sampling days. Both source signatures are in good agreement with the value of $-44.1 \%$ observed for desorbed methane of the Barnsley coal seam, in a study conducted by Hitchman et al. (1990b).

Kellingley colliery is a still open deep mine situated in North Yorkshire. A surface drainage plant for electrical power generation has been implemented (Holloway et al., 2005), and methane releases from the power plant might justify the mole fractions peak of 9 ppm that was observed while driving on the northern side of the coal mine on 10 July 2013. The Keeling plot analysis of the samples collected indicates a source signature of $-46.5 \pm 0.3 \%$ ( $2 \mathrm{SD})$.

The highest mole fractions detected around Thoresby mine, in Nottinghamshire, approached 5 ppm. Nine samples 
Table 1. $\delta^{13} \mathrm{C}_{\mathrm{CH}_{4}}$ signatures for all of the coal mines and coal basins surveyed with the Picarro mobile system. Errors in the $\delta^{13} \mathrm{C}$ signatures are calculated as 2 standard deviations.

\begin{tabular}{|c|c|c|c|c|c|c|c|}
\hline Sampling site & Country & Coal seam & Coal type & Mine type & $\begin{array}{l}\text { Sampling } \\
\text { date }\end{array}$ & $\begin{array}{l}\delta^{13} \mathrm{C} \\
\text { Signatures } \\
{[\% o]}\end{array}$ & $\begin{array}{l}\text { Samples } \\
\text { number } \\
\text { used in } \\
\text { Keeling } \\
\text { plots }\end{array}$ \\
\hline $\begin{array}{l}\text { Kellingley Colliery } \\
\text { (active) }\end{array}$ & North Yorkshire/UK & $\begin{array}{l}\text { Beeston and Silkstone coal } \\
\text { seams }\end{array}$ & $\begin{array}{l}\text { Bituminous } \\
\text { coal }\end{array}$ & Deep mine & $\begin{array}{l}\text { Sep } \\
2013\end{array}$ & $-46.5 \pm 0.3$ & 5 \\
\hline $\begin{array}{l}\text { Maltby Colliery } \\
\text { (closed since March } \\
2013 \text { ) }\end{array}$ & South Yorkshire/UK & $\begin{array}{l}\text { Barnsley and Parkgate seams, } \\
\text { up to } 991 \mathrm{~m} \text { in depth } \\
\text { (McEvoy et al., 2004) }\end{array}$ & $\begin{array}{l}\text { Bituminous } \\
\text { coal }\end{array}$ & Deep mine & $\begin{array}{l}\text { Jul } \\
2013 \\
\text { Sep } \\
2013\end{array}$ & $\begin{array}{l}-45.9 \pm 0.3 \\
-45.4 \pm 0.2\end{array}$ & $\begin{array}{l}3 \\
4\end{array}$ \\
\hline $\begin{array}{l}\text { Hatfield Colliery } \\
\text { (active) }\end{array}$ & South Yorkshire/UK & $\begin{array}{l}\text { Barnsley }(\sim 401-465 \mathrm{~m}), \\
\text { Dunsil }(414-376 \mathrm{~m}) \\
\text { High Hazel }(\sim 313-284 \mathrm{~m}) \\
\text { seams (Hill, 2001) }\end{array}$ & $\begin{array}{l}\text { Bituminous } \\
\text { coal }\end{array}$ & Deep mine & $\begin{array}{l}\text { Jul } \\
2013 \\
\text { Sep } \\
2013\end{array}$ & $\begin{array}{l}-48.3 \pm 0.2 \\
-48.8 \pm 0.3\end{array}$ & $\begin{array}{l}4 \\
5\end{array}$ \\
\hline $\begin{array}{l}\text { Thoresby Colliery } \\
\text { (active) }\end{array}$ & Nottinghamshire/UK & $\begin{array}{l}\text { Parkgate seam, } \sim 650 \mathrm{~m} \text { in } \\
\text { depth }\end{array}$ & $\begin{array}{l}\text { Bituminous } \\
\text { coal }\end{array}$ & Deep mine & $\begin{array}{l}\text { Nov } \\
2013\end{array}$ & $-51.2 \pm 0.3$ & 9 \\
\hline $\begin{array}{l}\text { Daw Mill Colliery } \\
\text { (closed since March } \\
\text { 2013) }\end{array}$ & Warwickshire/UK & $\begin{array}{l}\text { Warwickshire Thick seam, } \\
\text { from } 500 \text { to } 1000 \mathrm{~m} \text { in depth }\end{array}$ & $\begin{array}{l}\text { Bituminous } \\
\text { coal }\end{array}$ & Deep mine & $\begin{array}{l}\text { Nov } \\
2013\end{array}$ & $-51.4 \pm 0.2$ & 4 \\
\hline $\begin{array}{l}\text { Cwmllynfell } \\
\text { Colliery (active) }\end{array}$ & Wales/UK & South Wales Coalfield* & Anthracite & $\begin{array}{l}\text { Surface } \\
\text { mine }\end{array}$ & $\begin{array}{l}\text { Oct } \\
2013\end{array}$ & $-41.2 \pm 0.9$ & 3 \\
\hline $\begin{array}{l}\text { Abercrave Colliery } \\
\text { (active) }\end{array}$ & Wales/UK & South Wales Coalfield & Anthracite & $\begin{array}{l}\text { Surface } \\
\text { mine }\end{array}$ & $\begin{array}{l}\text { Oct } \\
2013\end{array}$ & $-41.4 \pm 0.5$ & 5 \\
\hline $\begin{array}{l}\text { Aberpergwm } \\
\text { Colliery (closed } \\
\text { since December } \\
\text { 2012) }\end{array}$ & Wales/UK & South Wales Coalfield & Anthracite & Deep mine & $\begin{array}{l}\text { Oct } \\
2013\end{array}$ & $-33.3 \pm 1.8$ & 5 \\
\hline $\begin{array}{l}\text { Unity Colliery } \\
\text { (active) }\end{array}$ & Wales/UK & South Wales Coalfield & Anthracite & Deep mine & $\begin{array}{l}\text { Oct } \\
2013\end{array}$ & $-30.9 \pm 1.4$ & 3 \\
\hline $\begin{array}{l}\text { Hunter Coalfield } \\
\text { (active) }\end{array}$ & Australia & Whittingham Coal Measures & $\begin{array}{l}\text { Bituminous } \\
\text { coal }\end{array}$ & $\begin{array}{l}\text { Surface } \\
\text { and deep } \\
\text { mines }\end{array}$ & $\begin{array}{l}\text { Mar } \\
2014\end{array}$ & $-66.4 \pm 1.3$ & 12 \\
\hline $\begin{array}{l}\text { Bulga Colliery } \\
\text { (active) }\end{array}$ & Australia & $\begin{array}{l}\text { Blakefield South seam, from } \\
130 \text { to } 510 \mathrm{~m} \text { in depth (Bulga } \\
\text { Underground Operation } \\
\text { mining, 2015) }\end{array}$ & $\begin{array}{l}\text { Bituminous } \\
\text { coal }\end{array}$ & Deep mine & $\begin{array}{l}\text { Jan } \\
2016\end{array}$ & $-60.8 \pm 0.3$ & 10 \\
\hline $\begin{array}{l}\text { Upper Silesian Basin } \\
\text { (active) }\end{array}$ & Poland & $\begin{array}{l}502(590-634 \mathrm{~m}) \text { and } 510 \text { seam } \\
(763-812 \mathrm{~m})\end{array}$ & $\begin{array}{l}\text { Bituminous } \\
\text { coal }\end{array}$ & Deep mine & $\begin{array}{l}\text { Jun } \\
2013\end{array}$ & $-50.9 \pm 1.2$ & 8 \\
\hline
\end{tabular}

* Only the coalfield is indicated, as the name of the seams exploited could not be retrieved.

were collected, giving a source signature of $-51.2 \pm 0.3 \%$ o (2 SD).

During the sampling of methane plumes from Daw Mill colliery, the highest methane mole fractions $(\sim 5 \mathrm{ppm})$ were recorded close to the edge of the colliery, whereas, driving downwind of the site at further distances, only background values were measured. Indeed, the estimated methane content of the coal seam exploited in Daw Mill colliery, closed in March 2013, is low (typically about $1.7 \mathrm{~m}^{3} \mathrm{t}^{-1}$ ) and, furthermore, a ventilation system is implemented, so that the coal mine methane potential is curtailed (Drake, 1983). Keel- ing plot analysis reveals a source signature of $-51.4 \pm 0.2 \%$ o (2 SD).

\subsection{Welsh coal mines}

Methane emissions from coal mines in Wales were sampled in order to characterise methane releases from a different rank of coal. The area investigated extended from Cwmllynfell to Merthyr Tydfil. The South Wales Coalfield is estimated to have the highest measured seam gas content in the UK (Creedy, 1991). 

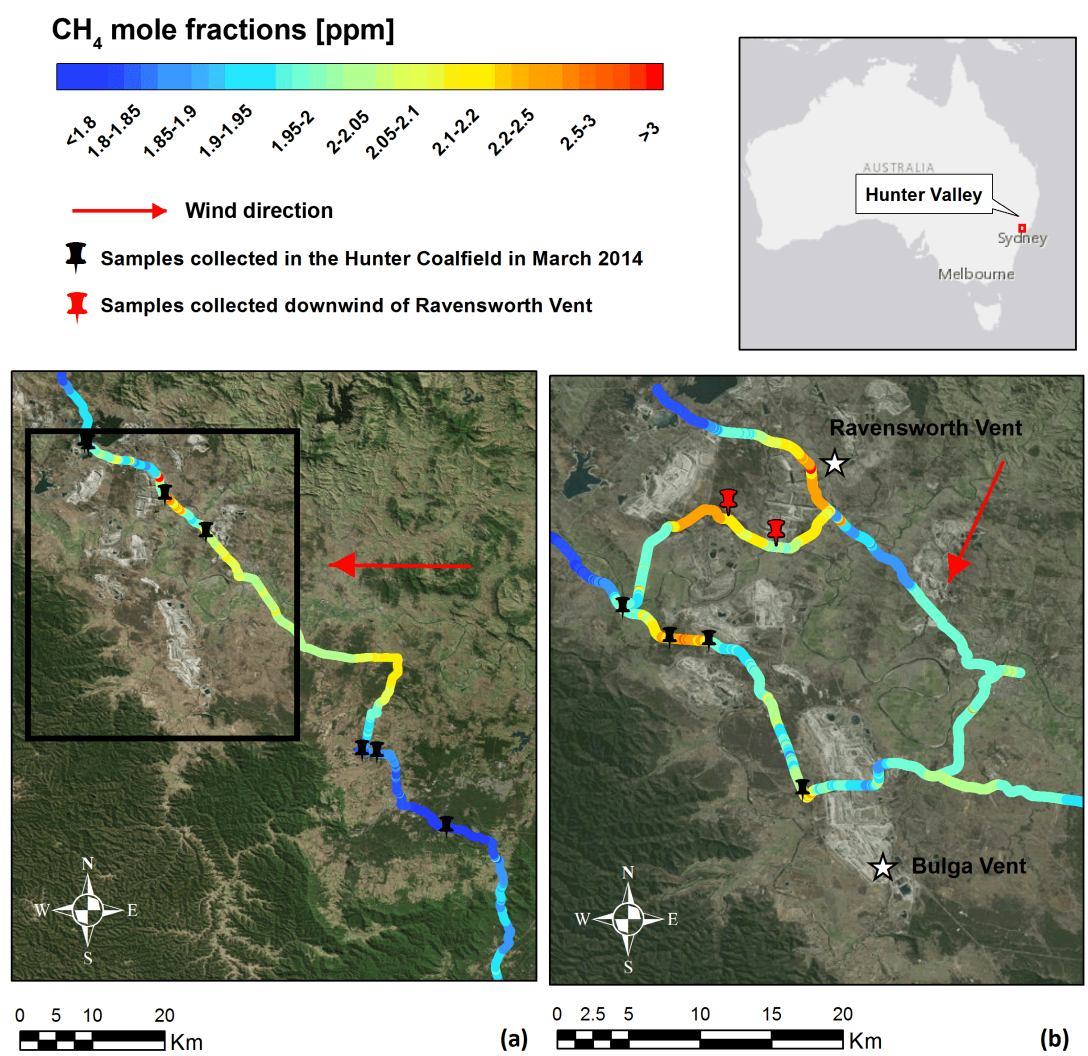

(a)

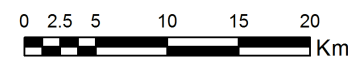

(b)

Figure 1. Methane mole fractions recorded in the Hunter Coalfield on 12 March 2014 (a) and during a more detailed survey of the area highlighted by the black square on 18 March 2014 (b). Source: Esri, DigitalGlobe, GeoEye, i-cubed, Earthstar Geographics, CNES/Airbus DS, USDA, USGS, AEX, Getmapping, Aerogrid, IGN, IGP, swisstopo and the GIS User Community.

\subsubsection{Deep mines}

The deep mine Aberpergwm, which closed in December 2012, did not operate coal mine methane schemes and methane was vented up to the surface as part of standard operation systems (Holloway et al., 2005). This is consistent with methane mole fractions peaks of $6 \mathrm{ppm}$ observed when approaching the colliery. Air samples were also collected near Unity deep mine, Wales' largest drift mine, which reopened in 2007 and is located in the town of Cwmgwrach, only $1.5 \mathrm{~km}$ away from Aberpergwm. Isotopic source signatures of $-33.3 \pm 1.8$ and $-30.9 \pm 1.4 \%$ result from the Keeling plots based on samples collected respectively near Aberpergwm and Unity colliery, both highly ${ }^{13} \mathrm{C}$ enriched relative to all English collieries.

\subsubsection{Opencast mines}

The Picarro mobile system was driven around opencast mines at Cwmllynfell and Abercrave, in the Swansea Valley. Up to $3 \mathrm{ppm}$ methane mole fractions were recorded near the two mines, which were closed in the 1960s as drift mines and are currently exploited as opencast mines. Our measurements confirm that they are still emitting methane, even though the methane mole fractions recorded downwind of the mines were not significantly above background. ${ }^{13} \mathrm{C}$ signatures between $-41.4 \pm 0.5$ and $-41.2 \pm 0.9 \%$ ( $2 \mathrm{SD}$ ) result from isotopic analysis of samples collected downwind of the opencast mines, approximately $10 \%$ o lower than the isotopic signature characterising Welsh deep anthracite mines.

\subsection{Polish coal mine}

A Picarro mobile survey of the Upper Silesian Basin took place on 10 June 2013 and 12 air samples were collected for isotopic analysis. All the mines in this area are deep mines, exploiting the coal at depths ranging from 300 to $900 \mathrm{~m}$. The Keeling plot analysis includes eight samples collected around the area of Radoszowy, downwind of the KWK Wujek deep mine shafts. Methane mole fractions in the range of $3-5 \mathrm{ppm}$ were measured in the majority of the area of Katowice and over $20 \mathrm{ppm}$ mole fractions were detected when transecting the plume originating from the exhaust shafts, which confirms the high level of methane that the mine contains. A source signature of $-50.9 \pm 0.6 \%$ ( $2 \mathrm{SD}$ ) was calculated by Keeling plot analysis, which is consistent with the values obtained for the deep mined English bituminous coal. 

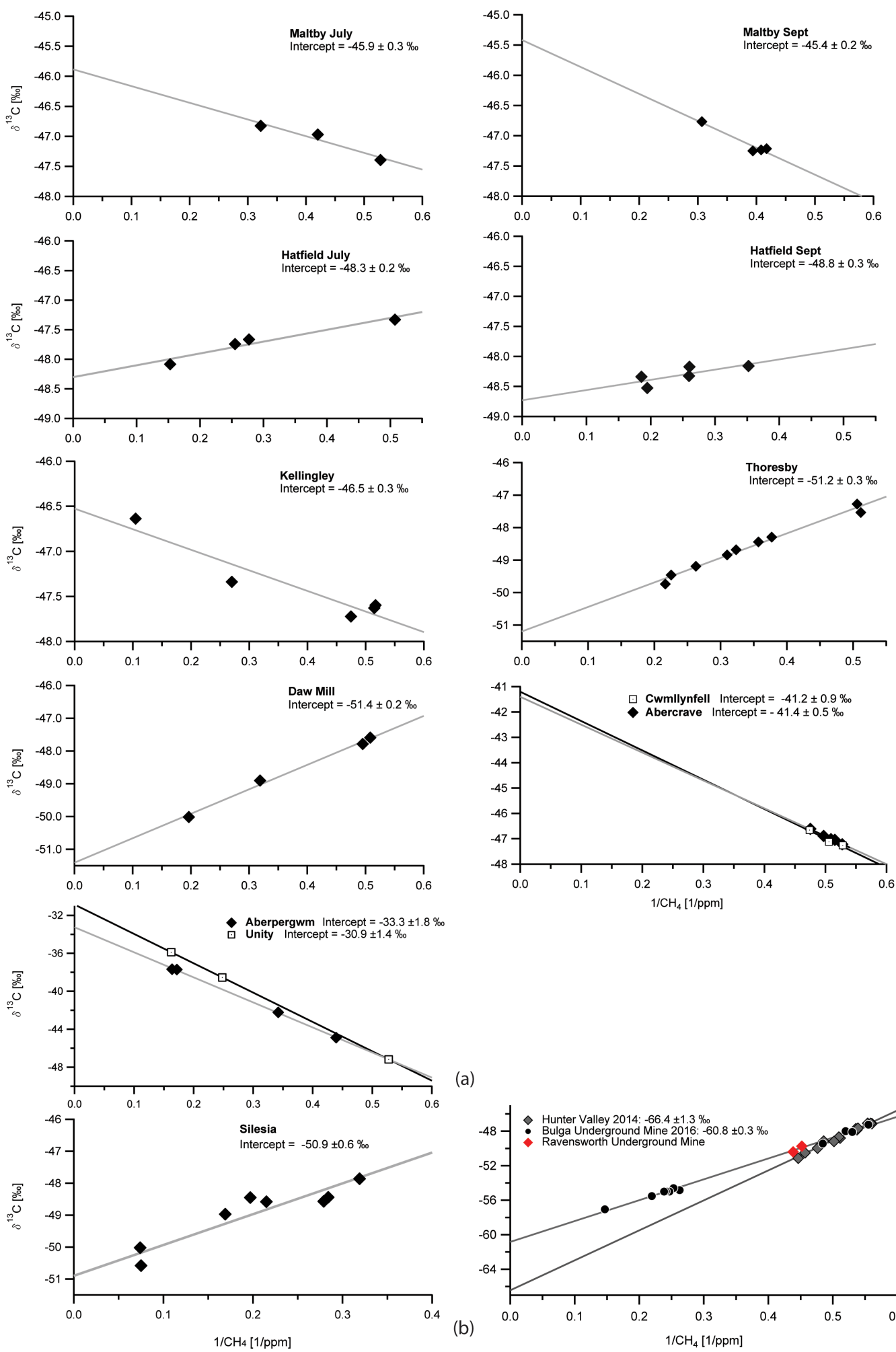

(a)

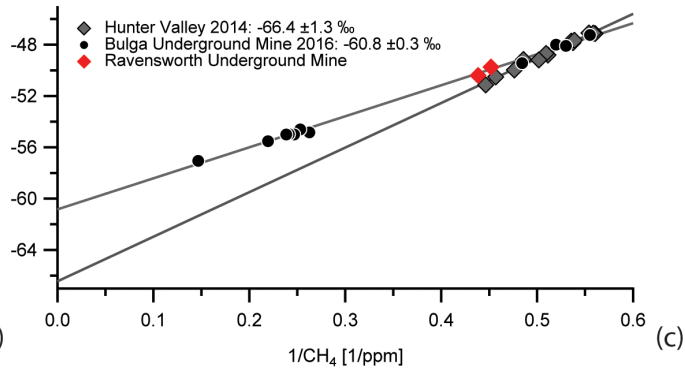

Figure 2. Keeling plots based on samples collected around English and Welsh coal mines (a), coal mines in Poland (b) and Australia (c). Errors on the $y$ axis are within $0.05 \%$ and on the $x$ axis within $0.0001 \mathrm{ppm}^{-1}$, and are not noticeable on the graph. 
Table 2. Literature-derived carbon isotopic ranges for methane from CBM (Coalbed Methane) wells in a wide range of sedimentary basins. Errors are not included as measurement precisions for the ranges of analytical techniques used are not specified.

\begin{tabular}{|c|c|c|c|c|}
\hline Site & Coal rank & $\delta^{13} \mathrm{C}(\% \circ)$ & Author & $\begin{array}{l}\delta^{13} \mathrm{C}(\% \circ) \\
\text { measured in } \\
\text { this study }\end{array}$ \\
\hline Powder River Basin, USA & Sub-bituminous coal & -79.5 to -56.8 & Bates et al. (2011) & \\
\hline Australia & $\begin{array}{l}\text { From brown coal to low volatile } \\
\text { bituminous coal }\end{array}$ & -73.0 to -43.5 & Smith et al. (1981) & $\begin{array}{l}-66.4 \pm 1.3 \text { to } \\
-55.5 \pm 1.3\end{array}$ \\
\hline Velenje Basin, Slovenia & Lignite & -71.8 to -43.4 & Kanduč et al. (2015) & \\
\hline Powder River Basin, USA & Sub-bituminous coal & -68.4 to -59.5 & Flores et al. (2008) & \\
\hline Illinois Basin, USA & Bituminous coal & -66.6 to -56.8 & Strąpoć et al. (2007) & \\
\hline Elk Valley Coalfield, Canada & Bituminous coal & -65.4 to -51.8 & Aravena et al. (2003) & \\
\hline Bowen Basin, Australia & Bituminous coal & -62.2 to -48 & Kinnon et al. (2010) & \\
\hline Queensland Basin, Australia & $\begin{array}{l}\text { From sub-bituminous to } \\
\text { high volatile bituminous }\end{array}$ & -57.3 to -54.2 & Papendick et al. (2011) & \\
\hline $\begin{array}{l}\text { Tara region, Queensland Basin, } \\
\text { Australia }\end{array}$ & $\begin{array}{l}\text { From sub-bituminous to } \\
\text { high volatile bituminous }\end{array}$ & -56.7 & Maher et al. (2014) & \\
\hline $\begin{array}{l}\text { San Juan Basin, New Mexico and } \\
\text { Colorado }\end{array}$ & High-volatile bituminous coal & -43.6 to -40.5 & Rice et al. (1989) & \\
\hline Michigan Basin, USA & Bituminous coal & -56 to -47 & Martini et al. (1998) & \\
\hline UK, Barnsley seam & Bituminous coal & -44.1 & $\begin{array}{l}\text { Hitchman et al. } \\
(1990 a, b)\end{array}$ & $\begin{array}{l}-48.8 \pm 0.3 \text { to } \\
-45.4 \pm 0.2\end{array}$ \\
\hline $\begin{array}{l}\text { Upper Silesian Coal Basin, } \\
\text { Poland }\end{array}$ & $\begin{array}{l}\text { Sub-bituminous coal to } \\
\text { anthracite }\end{array}$ & -79.9 to -44.5 & $\begin{array}{l}\text { Kotarba and Rice } \\
(2001)\end{array}$ & $-50.9 \pm 0.6$ \\
\hline Eastern China & Sub-bituminous to anthracite & -66.9 to -24.9 & Dai et al. (1987) & \\
\hline Ruhr basin, Germany & Bituminous coal, anthracite & $\begin{array}{l}-37 \\
(-60 \text { to }-14)\end{array}$ & Deines (1980) & \\
\hline Western Germany & $\begin{array}{l}\text { High-volatile bituminous to } \\
\text { anthracite }\end{array}$ & -70.4 to -16.8 & Colombo et al. (1966) & \\
\hline Eastern Ordos Basin, China & Bituminous coal & -42.3 to -39.8 & Guo et al. (2012) & \\
\hline $\begin{array}{l}\text { South-eastern Ordos Basin, } \\
\text { China }\end{array}$ & $\begin{array}{l}\text { Low-volatile bituminous and } \\
\text { semi-anthracite }\end{array}$ & -48.1 to -32.8 & Yao et al. (2013) & \\
\hline Qinshui, China & Anthracite & -41.4 to -34.0 & Qin et al. (2006) & \\
\hline Qinshui Basin, China & Semi-anthracite to anthracite & -36.7 to -26.6 & Su et al. (2005) & \\
\hline Sichuan Basin, China & Bituminous to anthracite & -36.9 to -30.8 & $\begin{array}{l}\text { Dai et al. (2012) } \\
\text { Xiong et al. (2004) }\end{array}$ & \\
\hline Wales, UK & Anthracite & & & $\begin{array}{l}-33.3 \pm 1.8 \text { to } \\
-30.9 \pm 1.4\end{array}$ \\
\hline
\end{tabular}

\subsection{Australia: Hunter Coalfield}

On 12 and 18 March 2014, 12 samples in total were collected along the route in the Hunter Coalfield, where the bituminous coal strata of the Sydney Basin are extracted, both in opencast and underground mines. The methane plume width was in the range of $70 \mathrm{~km}$ (Fig. 1). A maximum mole fraction of $13.5 \mathrm{ppm}$ was measured near a vent shaft associated with the Ravensworth underground mine (see white star in Fig. 1b). The source signature calculated by the Keeling plot analysis based on all the samples collected during both surveys (grey markers in Fig. 2c) is $-66.4 \pm 1.3 \%$ ( $2 \mathrm{SD}$ ) and this signature likely includes a mixture of methane derived both from underground and opencast mines. Two samples collected downwind of the Ravensworth ventilation shaft (red pushpins in Fig. 1b) fall off the Keeling plot trend for March 2014 and are not included in the calculation, because they are likely dominated by methane from the vent shaft and are not representative of the regional mixed isotopic signature.

In January 2016, 10 samples were collected downwind of a ventilation fan in the Bulga mine (second white star in Fig. 1b). The Keeling plot for these (black circles in Fig. 2c) indicates a $\delta^{13} \mathrm{C}$ source signature of $-60.8 \pm 0.3 \%$ ( $\left.2 \mathrm{SD}\right)$. The samples collected next to the Ravensworth ventilation shaft in 2014 fit on this Keeling plot, suggesting that the $\delta^{13} \mathrm{C}_{\mathrm{CH}_{4}}$ isotopic signature of emissions from underground works in the Hunter Coalfield is consistent. 


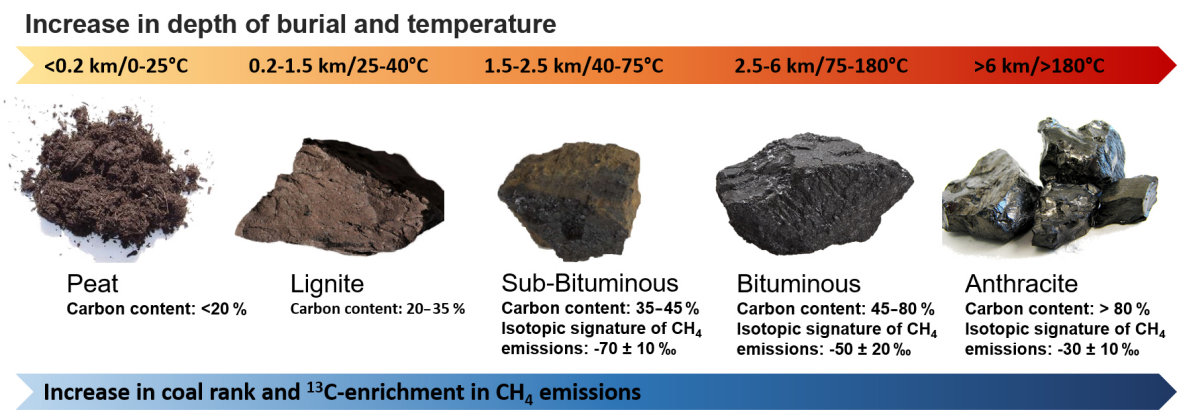

Figure 3. Coal maturation process. The $\delta^{13} \mathrm{C}_{\mathrm{CH}_{4}}$ signatures are based on the literature values in Table 2 and on the results of this study.

\subsection{New representative $\delta^{13} \mathrm{C}_{\mathrm{CH}_{4}}$ isotopic signatures for coal-derived methane}

The $\delta^{13} \mathrm{C}_{\mathrm{CH}_{4}}$ isotopic values for coal have been found to be characteristic of single basins, but general assumptions can be made to characterise coal mines worldwide. Table 2 provides the literature $\delta^{13} \mathrm{C}_{\mathrm{CH}_{4}}$ isotopic values characteristic of specific coal basins. The isotopic signatures of emissions from English bituminous coal are consistent with the range of -49 to $-31 \%$ o suggested by Colombo et al. (1966) for in situ coalbed methane in the Ruhr basin in Germany, which contains the most important German bituminous coal of Upper Carboniferous age and low volatile anthracite (Thomas, 2002). Progression in coal rank might explain the value of $-50 \%$ o for emissions from English underground mined bituminous coal and $-30 \%$ for anthracite deep mines, followed by a $5-10 \%{ }^{13} \mathrm{C}$-depletion likely caused by the incursion of meteoric water in the basin and the subsequent production of secondary biogenic methane (Scott et al., 1994), resulting in $-40 \%$ for methane plumes from Welsh open-cut anthracite mines.

The link between coal rank and $\delta^{13} \mathrm{C}_{\mathrm{CH}_{4}}$ isotopic signature is appreciable in the study of UK coal mines, but differences in the ${ }^{13} \mathrm{C} /{ }^{12} \mathrm{C}$ isotopic ratio within the same coal sequences could be ascribed to other parameters, such as the depth at which the coal is mined. As methane migrates towards the surface, diffusion or microbial fractionation may occur, especially if there is water ingress (see Sect. 1). In particular, emissions from Thoresby are more ${ }^{13} \mathrm{C}$ depleted than those measured around Maltby, although both mines exploit the Parkgate seam (see Table 1), meaning that different isotopic signatures cannot be entirely linked to the coal rank. Biogenic methane produced in a later stage due to water intrusion might have been mixed with the original thermogenic methane formed during the coalification process.

Differences in methane emissions and their isotopic signature between opencast and deep mines have been assessed by surveying both surface and underground mines, in the Welsh anthracite belt, and in the Hunter Coalfield. The shallower deposits are more exposed to the weathering and meteoric water, most likely associated with the production of some isotopically lighter microbial methane. Mole fractions up to $2.5 \mathrm{ppm}$ were measured around opencast mines in the Hunter Coalfield, in Australia, within a methane plume of more than $70 \mathrm{~km}$ width. The highest methane mole fractions were consistently measured downwind of vent shafts in underground mines. The difference in the source isotopic signature for methane emissions between the two types of mining, both in the Hunter Coalfield (from -61 to $-66 \%$ ) and in Wales (from -31 to $-41 \%$ ), reflects the isotopic shift of $5-10 \%$ o that might be attributed to the occurrence of secondary biogenic methane.

The $\delta^{13} \mathrm{C}$ signatures for coalbed methane emissions from the Upper Silesian Basin are highly variable, with the most ${ }^{13} \mathrm{C}$-depleted methane associated with diffusion processes or secondary microbial methane generation (Kotarba and Rice, 2001 ), but the value of $-51 \%$ measured for methane emissions from the KWK Wujek deep mine is consistent with the value of $-50 \%$ inferred for emissions from English bituminous coal extracted in underground mines.

Figure 3 shows the $\delta^{13} \mathrm{C}_{\mathrm{CH}_{4}}$ signatures for each coal type, based on the results of this study and isotopic values found in literature.

\section{Conclusions}

By measuring the isotopic signatures of methane plumes from a representative spread of coal types and depths, we show that the $\delta^{13} \mathrm{C}$ isotopic value to be included in regional and global atmospheric models for the estimate of methane emissions from the coal sector must be chosen according to coal rank and type of mining (opencast or underground). For low-resolution methane modelling studies, our measurements suggest an averaged value of $-65 \%$ for bituminous coal exploited in open cast mines and of $-55 \%$ or less negative, in deep mines, whereas values of -40 and $-30 \%$ can be assigned to anthracite opencast and deep mines respectively. However, the ranges of isotopic signatures of methane emitted from each of these categories are wide (see Fig. 3). Further measurements would be required in other coal mining areas, especially China, to determine appropriate val- 
ues for global modelling of methane isotopes. The overall bulk isotopic ratio of China's very large coal production is still very poorly quantified, but could be less depleted than $-40 \%$, as indicated by unpublished RHUL studies of winter air samples collected in Hong Kong with back trajectories that cross industrial China from Mt Waliguan in NW China.

Global methane budget models that incorporate isotopes have used a $\delta^{13} \mathrm{C}$ signature of $-35 \%$ for coal or a value $-40 \%$ for total fossil fuels (e.g. Hein et al., 1997; Mikaloff Fletcher et al., 2004; Bousquet et al., 2006; Monteil et al., 2011), but, given the relative rarity of anthracite global coal reserves and the dominance of bituminous coal (1 and 53\% respectively) (World Coal Institute, 2015), it seems likely that a global average emission from coal mining activities will be lighter, with the $-50 \%$ recorded for deep-mined bituminous coal in Europe being a closer estimate. However, for detailed global modelling of atmospheric methane, isotopic signatures of coal emissions should be region or nation specific, as greater detail is needed given the wide global variation. The assignment of an incorrect global mean, or use of a correct global mean that is inappropriate for regionalscale modelling, might lead to incorrect emissions estimates or source apportionment. The new scheme gives the possibility for an educated estimate of the $\delta^{13} \mathrm{C}$ signature of emission to the atmosphere to be made for an individual coal basin or nation, given information on the type of coal being mined and the method of extraction.

In conclusion, high-precision measurements of $\delta^{13} \mathrm{C}$ in plumes of methane emitted to the atmosphere from a range of coal mining activities have been used to constrain the isotopic range for specific ranks of coal and mine type, offering more representative isotopic signatures for use in methane budget assessment at regional and global scales.

\section{Data availability}

The isotopic ratios and mole fraction measurements used for the Keeling plots are included in the Supplement.

\section{The Supplement related to this article is available online at doi:10.5194/acp-16-13669-2016-supplement.}

Acknowledgements. Giulia Zazzeri would like to thank Royal Holloway, University of London for the provision of a Crossland scholarship and a contribution from the Department of Earth Sciences from 2011 to 2014. The analysis of samples from Poland was funded through the European Community's Seventh Framework Programme (FP7/2007-2013) in the InGOS project under grant agreement no. 284274. Sampling in Australia was possible due to a grant from the Cotton Research and Development Corporation.

Edited by: M. Heimann

Reviewed by: I. Levin and one anonymous referee

\section{References}

Akritas, M. G. and Bershady, M. A.: Linear regression for astronomical data with measurement errors and intrinsic scatter, Astrophys. J., 470, 706-714, 1996.

Alderton, D., Oxtoby, N., Brice, H., Grassineau, N., and Bevins, R.: The link between fluids and rank variation in the South Wales Coalfield: evidence from fluid inclusions and stable isotopes, Geofluids, 4, 221-236, 2004.

Aravena, R., Harrison, S., Barker, J., Abercrombie, H., and Rudolph, D.: Origin of methane in the Elk Valley coalfield, southeastern British Columbia, Canada, Chem. Geol., 195, 219227, 2003.

Bates, B. L., McIntosh, J. C., Lohse, K. A., and Brooks, P. D.: Influence of groundwater flowpaths, residence times and nutrients on the extent of microbial methanogenesis in coal beds: Powder River Basin, USA, Chem. Geol., 284, 45-61, 2011.

Bousquet, P., Ciais, P., Miller, J., Dlugokencky, E., Hauglustaine, D., Prigent, C., Van der Werf, G., Peylin, P., Brunke, E.-G., and Carouge, C.: Contribution of anthropogenic and natural sources to atmospheric methane variability, Nature, 443, 439-443, 2006.

Bulga Underground Operations Mining: Operation Plan 2015 to 2021, Blakefield South Mine Plan, available at: http://www.bulgacoal.com.au/EN/Publications/ MiningOperationsPlan/MiningOperationsPlan2015-2021.pdf, 2015.

Burra, A.: Application of domains in gas-in-place estimation for opencut coal mine fugitive gas emissions reporting, Bowen Basin Symposium, Mackay, Queensland, 6-8 October 2010, 59-64, 2010.

Chung, H. M. and Sackett, W. M.: Use of stable carbon isotope compositions of pyrolytically derived methane as maturity indices for carbonaceous materials, Geochim. Cosmochim. Ac., 43, 19791988, 1979.

Clayton, J.: Geochemistry of coalbed gas - A review, Int. J. Coal Geol., 35, 159-173, 1998.

Colombo, U., Gazzarrini, F., Gonfiantini, R., Kneuper, G., Teichmüller, M., and Teichmüller, R.: Carbon isotope study on methane from German coal deposits, in: Advances in Organic Geochemistry, edited by: Hobson, G. D. and Speers, G. C., 126, 1966.

Creedy, D. P.: An introduction to geological aspects of methane occurrence and control in British deep coal mines, Q. J. Eng. Geol., 24, 209-220, 1991.

Dai, J. X., Qi, H. F., Song, Y., and Guan, D. S.: Composition, carbon isotope characteristics and the origin of coal-bed gases in China and their implication, Sci. Sin. B-Chem. B. A. M., 30, 13241337, 1987.

Dai, J., Ni, Y., and Zou, C.: Stable carbon and hydrogen isotopes of natural gases sourced from the Xujiahe Formation in the Sichuan Basin, China, Org. Geochem., 43, 103-111, 2012.

Deines, P.: The isotopic composition of reduced organic carbon, Handbook of environmental isotope geochemistry, 329-406, 1980.

Drake, D.: Working the Warwickshire Thick Coal, Improved Techniques for the Extraction of Primary Forms of Energy, Springer Netherlands, 156-156, 1983.

Faiz, M. and Hendry, P.: Significance of microbial activity in Australian coal bed methane reservoirs - a review, B. Can. Petrol. Geol., 54, 261-272, 2006. 
Fisher, R., Lowry, D., Wilkin, O., Sriskantharajah, S., and Nisbet, E. G.: High-precision, automated stable isotope analysis of atmospheric methane and carbon dioxide using continuous-flow isotope-ratio mass spectrometry, Rapid Commun. Mass Sp., 20, 200-208, 2006.

Flores, R. M., Rice, C. A., Stricker, G. D., Warden, A., and Ellis, M. S.: Methanogenic pathways of coal-bed gas in the Powder River Basin, United States: the geologic factor, Int. J. Coal Geol., 76, 52-75, 2008.

Frodsham, K. and Gayer, R.: The impact of tectonic deformation upon coal seams in the South Wales coalfield, UK, Int. J. Coal Geol., 38, 297-332, 1999.

Fuex, A.: Experimental evidence against an appreciable isotopic fractionation of methane during migration, Phys. Chem. Earth, 12, 725-732, 1980.

Fung, I., John, J., Lerner, J., Matthews, E., Prather, M., Steele, L., and Fraser, P.: Three-dimensional model synthesis of the global methane cycle, J. Geophys. Res., 96, 13033-13065, 1991.

Guo, H., Yu, Z., Liu, R., Zhang, H., Zhong, Q., and Xiong, Z.: Methylotrophic methanogenesis governs the biogenic coal bed methane formation in Eastern Ordos Basin, China, Appl. Microbiol. Biot., 96, 1587-1597, 2012.

Hein, R., Crutzen, P. J., and Heimann, M.: An inverse modeling approach to investigate the global atmospheric methane cycle, Global Biogeochem. Cy., 11, 43-76, 1997.

Hill, A.: The South Yorkshire Coalfield: A History and Development, Tempus Books, Gloucestershire, 251 pp., 2001.

Hitchman, S., Darling, W., and Williams, G.: Stable isotope ratios in methane containing gases in the United Kingdom, British Geological Survey, Technical Report WE189i3, 1990a.

Hitchman, S., Darling, W., and Williams, G.: Stable isotope ratios in methane containing gases in the United Kingdom, Report of the British Geological Survey, Processes Research Group WE/89/30, 1990b.

Holloway, S., Jones, N., Creedy, D., and Garner, K.: Can new technologies be used to exploit the coal resources in the YorkshireNottinghamshire coalfield?: Carboniferous Hydrocarbon Geology: The Southern North Sea Surrounding Areas, Occasional publications of the Yorkshire Geological Society, 7, 195-208, 2005.

IMC Group Consulting Limited: A review of the remaining reserves at deep mines for the Department of Trade and Industry, 2002.

IPCC: 2006 IPCC guidelines for national greenhouse gas inventories: industrial processes and product use, Kanagawa, JP, Institute for Global Environmental Strategies, 2006.

Jureczka, J. and Kotas, A.: Coal deposits - Upper Silesian Coal Basin, The carboniferous system in Poland, 148, 164-173, 1995.

Kanduč, T., Grassa, F., Lazar, J., and Zavšek, S.: Geochemical and isotopic characterization of coalbed gases in active excavation fields at Preloge and Pesje (Velenje Basin) mining areas, RMZ$\mathrm{M} \& \mathrm{G}, 62,21-36,2015$.

Keqdzior, S.: Accumulation of coal-bed methane in the south-west part of the Upper Silesian Coal Basin (southern Poland), Int. J. Coal Geol., 80, 20-34, 2009.

Kotarba, M. J. and Rice, D. D.: Composition and origin of coalbed gases in the Lower Silesian basin, southwest Poland, Appl. Geochem., 16, 895-910, 2001.

Kinnon, E., Golding, S., Boreham, C., Baublys, K., and Esterle, J.: Stable isotope and water quality analysis of coal bed methane production waters and gases from the Bowen Basin, Australia, Int. J. Coal Geol., 82, 219-231, 2010.

Levin, I., Bergamaschi, P., Dörr, H., and Trapp, D.: Stable isotopic signature of methane from major sources in Germany, Chemosphere, 26, 161-177, 1993.

Liptay, K., Chanton, J., Czepiel, P., and Mosher, B.: Use of stable isotopes to determine methane oxidation in landfill cover soils, $\mathrm{J}$. Geophys. Res.-Atmos, 103, 8243-8250, 1998.

Locatelli, R., Bousquet, P., Chevallier, F., Fortems-Cheney, A., Szopa, S., Saunois, M., Agusti-Panareda, A., Bergmann, D., Bian, H., Cameron-Smith, P., Chipperfield, M. P., Gloor, E., Houweling, S., Kawa, S. R., Krol, M., Patra, P. K., Prinn, R. G., Rigby, M., Saito, R., and Wilson, C.: Impact of transport model errors on the global and regional methane emissions estimated by inverse modelling, Atmos. Chem. Phys., 13, 99179937, doi:10.5194/acp-13-9917-2013, 2013.

Lowry, D., Holmes, C. W., Rata, N. D., O’Brien, P., and Nisbet, E. G.: London methane emissions: Use of diurnal changes in concentration and $\delta^{13} \mathrm{C}$ to identify urban sources and verify inventories, J. Geophys. Res.-Atmos., 106, 7427-7448, 2001.

McEvoy, F. M., Minchin, D., Harrison, D. J., Cameron, D. G., Burke, H. F., Spencer, N. A., Evans, D. J., Lott, G. K., Hobbs, S. F., and Highley, D. E.: Mineral Resource Information in Support of National, Regional and Local Planning, South Yorkshire (comprising Metropolitan Boroughs of Barnsley, Doncaster and Rotherham and City of Sheffield) British Geological Survey Commissioned Report, 2004.

Maher, D. T., Santos, I. R., and Tait, D. R.: Mapping methane and carbon dioxide concentrations and $\delta^{13} \mathrm{C}$ values in the atmosphere of two Australian coal seam gas fields, Water Air Soil Poll., 225, $1-9,2014$.

Martini, A., Walter, L., Budai, J., Ku, T., Kaiser, C., and Schoell, M.: Genetic and temporal relations between formation waters and biogenic methane: Upper Devonian Antrim Shale, Michigan Basin, USA, Geochim. Cosmochim. Ac., 62, 1699-1720, 1998.

Mikaloff Fletcher, S. E., Tans, P. P., Bruhwiler, L. M., Miller, J. B., and Heimann, M.: $\mathrm{CH}_{4}$ sources estimated from atmospheric observations of $\mathrm{CH} 4$ and its ${ }^{13} \mathrm{C} /{ }^{12} \mathrm{C}$ isotopic ratios: 2. Inverse modeling of $\mathrm{CH}_{4}$ fluxes from geographical regions, Global Biogeochem. Cy., 18, GB4005, doi:10.1029/2004GB002224, 2004.

Miller, J. B.: The carbon isotopic composition of atmospheric methane and its constraints on the global methane budget, Stable Isotopes and Biosphere-Atmosphere Interactions: Processes and Biological Controls, Elsevier Academic Press California, 288306, 2004.

Monteil, G., Houweling, S., Dlugockenky, E. J., Maenhout, G., Vaughn, B. H., White, J. W. C., and Rockmann, T.: Interpreting methane variations in the past two decades using measurements of $\mathrm{CH}_{4}$ mixing ratio and isotopic composition, Atmos. Chem Phys., 11, 9141-9153, doi:10.5194/acp-11-9141-2011, 2011.

Nisbet, E. G., Dlugokencky, E. J., and Bousquet, P.: Methane on the rise-again, Science, 343, 493-495, 2014.

O'Keefe, J. M., Bechtel, A., Christanis, K., Dai, S., DiMichele, W. A., Eble, C. F., Esterle, J. S., Mastalerz, M., Raymond, A. L., and Valentim, B. V.: On the fundamental difference between coal rank and coal type, Int. J. Coal Geol., 118, 58-87, 2013.

Papendick, S. L., Downs, K. R., Vo, K. D., Hamilton, S. K., Dawson, G. K., Golding, S. D., and Gilcrease, P. C.: Biogenic 
methane potential for Surat Basin, Queensland coal seams, Int. J. Coal Geol., 88, 123-134, 2011.

Pataki, D. E., Bowling, D. R., and Ehleringer, J. R.: Seasonal cycle of carbon dioxide and its isotopic composition in an urban atmosphere: Anthropogenic and biogenic effects, J. Geophys. Res.Atmos., 108, 4735, doi:10.1029/2003JD003865, 2003.

Patyńska, R.: Prognoza wskaźników emisji metanu z kopalń metanowych węgla kamiennego w Polsce, Polityka Energetyczna, 16, 157-169, 2013.

Pinetown, K.: Regional coal seam gas distribution and burial history of the Hunter Coalfield, Sydney Basin, Aust. J. Earth Sci., 61, 409-426, 2014.

Qin, S., Tang, X., Song, Y., and Wang, H.: Distribution and fractionation mechanism of stable carbon isotope of coalbed methane, Sci. China Ser. D, 49, 1252-1258, 2006.

Rice, D. D.: Composition and origins of coalbed gas: Hydrocarbons from coal, AAPG Studies in Geology, 38, 159-184, 1993.

Rice, D. D., Clayton, J. L., and Pawlewicz, M. J.: Characterization of coal-derived hydrocarbons and source-rock potential of coal beds, San Juan Basin, New Mexico and Colorado, USA, Int. J. Coal Geol., 13, 597-626, 1989.

Scott, A. R.: Hydrogeologic factors affecting gas content distribution in coal beds, Int. J. Coal Geol., 50, 363-387, 2002.

Scott, A. R., Kaiser, W., and Ayers Jr., W. B.: Thermogenic and secondary biogenic gases, San Juan Basin, Colorado and New Mexico - implications for coalbed gas producibility, AAPG bulletin, 78, 1186-1209, 1994.

Smith, J. W., Gould, K., and Rigby, D.: The stable isotope geochemistry of Australian coals, Org. Geochem., 3, 111-131, 1981.

Stach, E. and Murchison, D. G.: Stach's Textbook of coal petrology, Borntraeger, Stuttgart, 426 pp., 1982.

State of New South Wales, Department of Trade \& Investment, Division of Resources \& Energy: 2013 New South Wales Coal Industry profile, 2013.

Strąpó́, D., Mastalerz, M., Eble, C., and Schimmelmann, A.: Characterization of the origin of coalbed gases in southeastern Illinois Basin by compound-specific carbon and hydrogen stable isotope ratios, Org. Geochem., 38, 267-287, 2007.

Su, X., Lin, X., Liu, S., Zhao, M., and Song, Y.: Geology of coalbed methane reservoirs in the Southeast Qinshui Basin of China, Int. J. Coal Geol., 62, 197-210, 2005.

Thomas, L.: Coal geology, John Wiley \& Sons, 444 pp., 2002.

Townsend-Small, A., Tyler, S. C., Pataki, D. E., Xu, X. M., and Christensen, L. E.: Isotopic measurements of atmospheric methane in Los Angeles, California, USA: Influence of "fugitive" fossil fuel emissions, J. Geophys. Res.-Atmos., 117, D07308, doi:10.1029/2011JD016826, 2012.
US EPA: Global Anthropogenic Non- $\mathrm{CO}_{2}$ Greenhouse Gas Emissions: 1990-030, USEPA, Washington, DC, EPA 430-R-12-006, 2012.

US EPA: US Environmental Protection Agency, Global Mitigation of Non- $\mathrm{CO}_{2}$ Greenhouse Gases: 2010-2030, USEPA, Washington, DC, EPA-430-R-13-011, 2013.

Waldron, S., Fallick, A., and Hall, A.: Comment on "Spatial distribution of microbial methane production pathways in temperate zone wetland soils: Stable carbon and hydrogen evidence" by Hornibrook, E. R. C., Longstaffe, F. J., and Fyfe, W. S., Geochim. Cosmochim. Ac., 62, 369-372, 1998.

Ward, C. and Kelly, B. F. J.: Background Paper on New South Wales Geology: with a focus on basins containing coal seam gas resources, UNSW Global, The University of New South Wales, a report prepared for the Office of the NSW Chief Scientist and Engineer, 2013.

Whiticar, M. and Schaefer, H.: Constraining past global tropospheric methane budgets with carbon and hydrogen isotope ratios in ice, Philos. T. R. Soc. S.-A, 365, 1793-1828, 2007.

Whiticar, M. J.: Stable isotope geochemistry of coals, humic kerogens and related natural gases, Int. J. Coal Geol., 32, 191-215, 1996.

Whiticar, M. J.: Carbon and hydrogen isotope systematics of bacterial formation and oxidation of methane, Chem. Geol., 161, 291314, 1999.

World Coal Institute: The coal resource, a comprehensive overview of coal: http://www.worldcoal.org/, 2015.

Xiong, Y., Geng, A., and Liu, J.: Kinetic-simulating experiment combined with GC-IRMS analysis: application to identification and assessment of coal-derived methane from Zhongba Gas Field (Sichuan Basin, China), Chem. Geol., 213, 325-338, 2004.

Yao, Y., Liu, D., and Qiu, Y.: Variable gas content, saturation, and accumulation characteristics of Weibei coalbed methane pilotproduction field in the southeastern Ordos Basin, China, AAPG bulletin, 97, 1371-1393, 2013.

Zazzeri, G., Lowry, D., Fisher, R., France, J., Lanoisellé, M., and Nisbet, E.: Plume mapping and isotopic characterisation of anthropogenic methane sources, Atmos. Environ., 110, 151-162, 2015 . 